\title{
The Development of Character-Based Assessment Instruments in Poetry Writing Material for Class X Students of SMA Negeri 3 Medan
}

\author{
Muhammad Sadri ${ }^{1}$, Abdurahman Adisaputera ${ }^{2}$, Syahnan Daulay ${ }^{3}$ \\ ${ }^{1,2,3}$ Universitas Negeri Medan, Indonesia \\ muhammadsadrikoto@gmail.com
}

\begin{abstract}
Early observations made on the Indonesian language teacher, Henny Indriany, S.Pd. at SMAN 3 Medan, explained that the assessment instrument carried out by the teacher was only on the selected assessment technique according to the characteristics or abilities of students. Whereas the assessment process in writing scientific papers is very good and effective if the principles of this assessment are considered when the teacher is: (1) there are clear restrictions on what is prioritized for assessment. (2) the selected assessment technique must be in accordance with the characteristics or abilities to be measured. (3) comprehensive assessment requires various types of assessment techniques. (4) should be aware that the assessment techniques used have limitations. (5) the assessment must be used to improve the learning achievement of students. Data regarding the quality of the character assessment instrument based on rational data (validator assessment) is taken using a validation sheet filled in by experts in the field of educational assessment, and the preparation of a psychological scale. The expert validation sheet consists of four answer scores, namely 1,2, 3, and 4. The number of questions is 20 items so that the range of scores obtained is between 20-80. The results obtained are converted into the following eligibility criteria. Learning Indonesian, especially writing poetry based on character education which is served to students, aims to train students to be skilled in language, especially writing by expressing ideas andfeelings creatively and critically. Learning to write poetry in high school according to the 2013 Curriculum aims to improve the skills of students in appropriate and creative language, increase the ability to think logically, critically and reason, and increase the sensitivity of feelings and the ability of students to understand and implement the values of character education in everyday life. day and in the school environment.
\end{abstract}

Keywords development character; assesment instruments; poetry writing

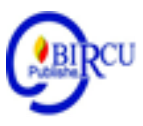

\section{Introduction}

Assessment is an activity that has an important role and provides benefits for the achievement of student learning outcomes. One of the benefits of the assessment is that it is used as feedback for students and teachers. For students, the assessment functions to measure the extent of students' abilities, while for teachers the assessment functions to improve the activities and methods used in the learning process. This is reinforced by Djiwandono (2011: 2) who states that "Assessment is an inseparable part of the 
implementation of learning as a whole". The position of assessment in design is as part of the implementation of learning as part of a series of three main components of implementation, namely learning objectives, learning activities, and assessment of learning outcomes.

The implementation of assessments carried out correctly will ensure an increase in the quality of learning. Assessment of learning outcomes is an integral part of the whole process of teaching and learning activities. This is reinforced by Nurgiyantoro (2012: 5) which states that all components of the learning system influence each other and determine one another so that if all components work well, they will definitely produce maximum output. The existence of feedback from the results of the assessment can be seen as an effort to improve the quality of the process and the learning outcomes that are held. Based on the results of previous assessment activities, we will find out what competencies have, not, or are not mastered by students and therefore further actions can be taken.

Early observations made on the Indonesian language teacher, Henny Indriany, S.Pd. at SMAN 3 Medan, explained that the assessment instrument carried out by the teacher was only on the selected assessment technique according to the characteristics or abilities of students. Whereas the assessment process in writing scientific papers is very good and effective if the principles of this assessment are considered when the teacher is: (1) there are clear restrictions on what is prioritized for assessment. (2) the selected assessment technique must be in accordance with the characteristics or abilities to be measured. (3) comprehensive assessment requires various types of assessment techniques. (4) should be aware that the assessment techniques used have limitations. (5) the assessment must be used to improve the learning achievement of students (Grondlund \& Linn, 1990.

\section{Review of Literatures}

\subsection{Research and Development}

In the large Indonesian dictionary the word "development" is etymologically meaningful, meaning the process / way, the act of developing. Definition

Another explanation explained by Sutopo and Westy (1993: 45) in terms, the word development shows an activity to produce a new tool or method, during which the assessment and improvement of the tool or method continues to be carried out. If, after experiencing refinements, finally the tool or method is deemed stable enough to be used continuously, the development activity will end.

According to the Law of the Republic of Indonesia Number 18 of 2002 Development is a science and technology activity that aims to utilize proven scientific principles and theories to improve the functions, benefits and applications of existing science and technology or to produce new technology. Development generally means a pattern of growth, gradual change (evolution) and gradual change.

The definition of research and development expressed by Borg and Gall (Sugiyono. 2015: 28) is a process or method used to validate and develop products or in other terms research and development functions to validate and develop products. Validating a product means that the product already exists, and the researcher is only testing the effectiveness or validity of the product. Developing a product in a broad sense can be in the form of updating the product existing products so that they become more practical, effective, and efficient or create new products that have never existed before. 


\subsection{Definition of Assessment Instruments}

According to Permendikbud No. 104 of 2014 the instrument is a tool that meets academic requirements, so that it can be used as a measuring tool to measure a measuring object or collect data about a variable. assessment and evaluation is an effort to collect data which is then processed for policy making in an educational program (Sani in Siregar, 2020). Meanwhile, the assessment instrument is a tool used to assess student learning outcomes, for example tests and attitude scales. Assessment is part of the learning process of daily activities that are carried out continuously. Assessment is the most important part of learning, because this is the most effective strategy to help identify students in learning. Yohana (2019) states that an assessment is developed to see the achievement of the applicable curriculum standard assessment. The result of the assessment is the initial process before making decisions about the next steps in improving students' ability to understand student learning (Amnie, 2016: 59).

\subsection{Character Building}

Character education is a term that is increasingly getting recognition from the Indonesian people today. Especially with the feeling of various inequalities in educational outcomes seen from the behavior of current formal education graduates, such as corruption, the development of free sex among adolescents, drugs, murder fights, robbery by students, and unemployed high school graduates. Everything feels stronger when this country is hit by crisis and does not move from the crisis it is experiencing.

\subsection{Writing Poetry}

Poetry is the oldest form of literature. The great monumental works of the world are written in the form of poetry. Poetry is not only used for writing great works, but it turns out that poetry is also very closely related to our daily lives. As for the things that need to be considered in writing poetry:

1. Poetry is created in an atmosphere of intense feeling that demands a spontaneous and concise pronunciation of the soul. In poetry, a person speaks and expresses himself in an expressive way. This is different from prose, where the author does not always reveal himself, but can also talk about other people and their other worlds.

2. Poetry writers should be based on problems or various things that touch the writer's own consciousness. Written themes for poetry should depart from unique self-inspiration, no matter how small and simple the inspiration may be.

3. In the case of writing poetry, you must think about how to convey it. The way of conveying ideas or feelings in poetry is called language style or figure of speech.

\section{Research Method}

The research was conducted at SMA Negeri 3 Medan, which is located at Jalan Budi Kemasyarakatan No. 3 Medan in September 2018 - October 2018.

The population in this study were all students of class X SMA Negeri 3 Medan who came from 19 class X MIA. Samples taken came from class X MIA 1, X MIA 5, X MIA 10, and $X$ IS 1. The sampling technique used simple random sampling technique. For the small scale test, the students of class X MIA 5 were used. In the large scale test, the students of class X MIA 1, X MIA 10, and X IS 1 were used.

Data regarding the quality of the character assessment instrument based on rational data (validator assessment) is taken using a validation sheet filled in by experts in the field of educational assessment, and the preparation of a psychological scale. The expert 
validation sheet consists of four answer scores, namely 1, 2, 3, and 4. The number of questions is 20 items so that the range of scores obtained is between 20-80. The results obtained are converted into the following eligibility criteria.

$\%=\frac{n}{N} x 100$

Information:

$\%=$ aspect percentage

$\mathrm{n}=$ score achieved

$\mathrm{N}=$ maximum score

The percentage of eligibility aspects obtained is matched with the eligibility criteria listed in table 1.

Table 1. Eligibility Criteria for Character Assessment Scale by Validator

\begin{tabular}{|l|l|}
\hline Eligibility Criteria & Category \\
\hline $25 \%-43 \%$ & Not feasible \\
\hline $44 \%-62 \%$ & Not worth it \\
\hline $63 \%-81 \%$ & Well worth it \\
\hline $82 \%-100 \%$ & Very Worth it \\
\hline
\end{tabular}

Data regarding the quality of the character assessment instrument based on empirical data (validity and reliability) were taken from the results of the scale readability test, computational validity and reliability tests using IBM SPSS Statistics21.0 for Windows, observation sheets and interview guides for applicability with Indonesian language teachers class X SMA Negeri 3Medan.

The scale readability data were collected using a readability test sheet. In the readability test sheet students are asked to fill in one of the three response columns provided, namely difficult to understand, sufficiently understanding, and easy to understand related to easily understanding the intent of the item, along with the comment column.

The results of small-scale trials were processed using formulas

$P=\frac{f}{N} x 100 \%$

Information:

$\mathrm{P}=$ percentage of the respondent's readability

$\mathrm{f}=$ score achieved by the item

$\mathrm{N}=$ maximum item score

The results of the small-scale trial were matched with table 3.2 which contained the scale and category readability criteria for these criteria.

Table 2. Readability Criteria

\begin{tabular}{|l|l|}
\hline Readability Criteria & Category \\
\hline $33 \%-49 \%$ & Low \\
\hline $50 \%-66 \%$ & Enough \\
\hline $67 \%-83 \%$ & High \\
\hline $84 \%-100 \%$ & Very high \\
\hline
\end{tabular}


Validity and reliability testing to measure the feasibility of scale items character assessment using the following formula

Item validation can be measured by the product moment correlation formula with rough numbers (Arikunto, 2009: 78)

$$
r_{x y}=\frac{n\left(\sum X Y\right)-\left(\sum X\right)\left(\sum Y\right)}{\sqrt{\left\{n \sum X^{2}-\left(\sum X\right)^{2}\right\}\left\{n \sum Y^{2}-\left(\sum Y\right)^{2}\right\}}}
$$

Information :

$r_{x y}=$ Shows the correlation index between two correlated variables

$R=$ Coefficient of the validity of the item sought, the two variables being correlated

$X=$ Score for the selected statement

$Y=$ The total score obtained from all items

$\sum X=$ The sum of the scores in the $\mathrm{X}$ distribution

$\sum Y=$ The sum of the scores in the $\mathrm{Y}$ distribution

$\sum X 2=$ The sum of squares in the $\mathrm{X}$ distribution score

$\sum Y 2=$ The sum of squares in the score distribution $\mathrm{Y}$

$N=$ Number of respondents

Items with a validity coefficient greater than the critical $r$ value for 150 samples with a significance level of $5 \%$, namely 0,159 are said to be valid.

The reliability of item scores was measured using the $\alpha$ formula (Arikunto, 2009: 29).

$$
r_{11}=\left(\frac{n}{n-1}\right)\left(1-\frac{\sum \sigma_{i}^{2}}{\sum \sigma_{t}^{2}}\right)
$$

Information:

$r_{11} \quad=$ reliability coefficient

$n \quad=$ number of items

$\sum \sigma_{i}^{2}=$ number of score variants for each item

$\sigma_{t}^{2}=$ total variant

The $\alpha$ formula is used to analyze the reliability of item scores with a single test administration approach which results in an estimate of the reliability of internal item consistency (Azwar, 2013b: 115). The results of the calculation of the item score reliability obtained were then consulted with the reliability criteria as outlined in table 3.3 below

Table 3. Reliability Criteria

\begin{tabular}{ll}
\hline Reliability coefficient & Category \\
\hline $\mathbf{r}<\mathbf{0 . 2}$ & Very low \\
$\mathbf{0 . 2} \leq \mathbf{r}<\mathbf{0 . 4}$ & Low \\
$\mathbf{0 . 4} \leq \mathbf{r}<\mathbf{0 . 6}$ & Moderate \\
$\mathbf{0 . 6} \leq \mathbf{r}<\mathbf{0 . 8}$ & High \\
$\mathbf{0 . 8} \leq \mathbf{r}<\mathbf{1 . 0}$ & Very high \\
\hline
\end{tabular}


Based on predetermined criteria, items that pass the selection are items that have validity $\geq 0.159$ and reliability $\geq 0.60$. Items that pass the selection are then arranged in the final format of the character rating scale according to the predefined character grading scale grid. Items that do not pass the selection or do not meet the criteria can be eliminated.

Data on the applicability of character assessment instruments based on empirical data were also collected using observation sheets and applied interview guides with Indonesian language teachers in class X SMA Negeri 3Medan. The observation sheet consists of 10 statements with 2 answer scores, namely 0 and 1 . The formula used to analyze the applicability of the character assessment instrument is as follows:

$P=\frac{f}{N} x 100 \%$

Information:

$\mathrm{P}=$ percentage of the respondent's readability

$\mathrm{f}=$ score achieved by the item

$\mathrm{N}=$ maximum item score

The results of the calculation of the score for the applied level obtained are matched with the applied criteria in table 3.4 below

Table 4. Criteria for the Applicability of the Character Rating Scale

\begin{tabular}{|l|l|}
\hline Applicability Criteria & Category \\
\hline $0 \%-20 \%$ & Very low \\
\hline $21 \%-40 \%$ & Low \\
\hline $41 \%-60 \%$ & Enough \\
\hline $61 \%-80 \%$ & High \\
\hline $81 \%-100 \%$ & Very high \\
\hline
\end{tabular}

Table 5. Instrument Validity and Reliability

\begin{tabular}{|l|l|l|l|}
\hline No. & Collected Data & Instrument & $\begin{array}{l}\text { Validity and Reliability } \\
\text { Techniques }\end{array}$ \\
\hline 1. & $\begin{array}{l}\text { The instrument } \\
\text { model used in } \\
\text { MAA 3 3 } \\
\text { Medan }\end{array}$ & Interview guide & $\begin{array}{l}\text { Face validity checked by } \\
\text { the supervisor }\end{array}$ \\
\hline 2. & $\begin{array}{l}\text { Quality character } \\
\text { issessment } \\
\text { instrument }\end{array}$ & Validation sheet & $\begin{array}{l}\text { Content validation by } \\
\text { educational assessment } \\
\text { experts, and psychology } \\
\text { scaling experts }\end{array}$ \\
\hline 3. & $\begin{array}{l}\text { Quality } \\
\text { assessment } \\
\text { instruments based } \\
\text { on empirical data }\end{array}$ & $\begin{array}{l}\text { Computing validity and } \\
\text { reliability tests, } \\
\text { observation sheets, and } \\
\text { applied interview guides } \\
\text { with Indonesian language } \\
\text { teachers in class XI SMA } \\
\text { Negeri 3 Medan. }\end{array}$ & $\begin{array}{l}\text { Face validity checked by } \\
\text { the supervisor }\end{array}$ \\
\hline
\end{tabular}




\section{Discussion}

The description of the character-based assessment instrument product on writing poetry at SMA Negeri 3 Medan is as follows:

\subsection{Product Identity}

Physical Materials : Printing Materials (printed material)

Title : Assessment Instruments character based

Theory

: Writing poetry

Target

: Class students X SMA Negeri Medan

Author Name

: Muhammad Sadri

\section{a. Book Cover}

The cover of a book with the material of Writing poetry has a front and a back. Here's the explanation

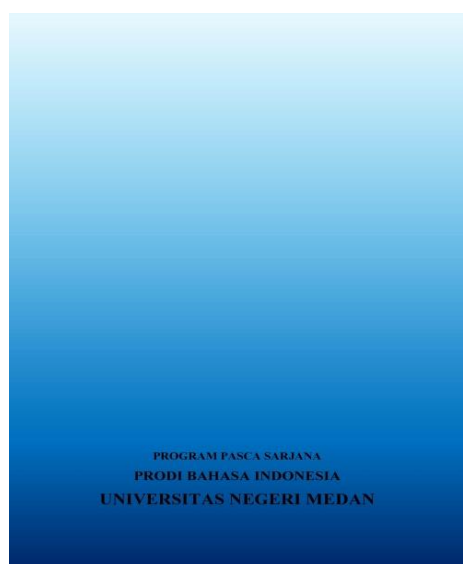

Figure 1. Book Cover

The front cover of the teaching material consists of the name of the compiler, the title of the assessment instrument according to the material being developed. The background is adjusted to the assessment in the book, there is a picture of the atmosphere in the classroom, there are also students. This is intended to make it look attractive and the reader is able to know the meaning of the title and illustration before opening the assessment instrument.

\section{b. Foreword}

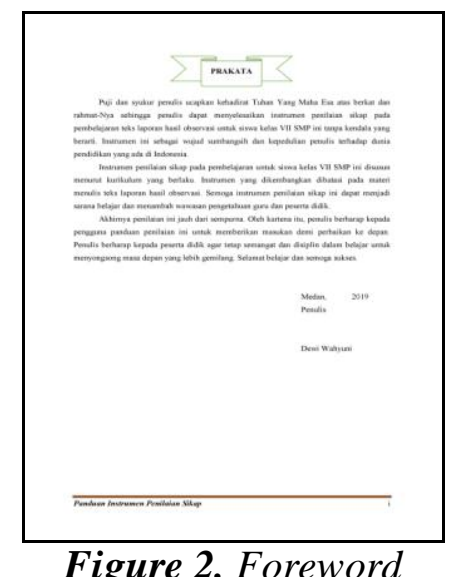

Figure 2. Foreword 
The foreword is placed on the first page of the book to open the author's communication with the reader. The content of the foreword is the author's attempt to communicate with the reader, by applying several types of principles, namely: 1) giving the impression that the assessment instrument is properly structured and important to read and study, 2) the superiority of the content presented in the assessment instrument, 3) the author's expectations regarding with prospects for education and the perfection of the assessment instrument.

\subsection{Learning Activities}

Learning material contains material that has been determined in accordance with KI, $\mathrm{KD}$, indicators and learning objectives in the hope that teachers and students can find out the results obtained.

\subsection{Bibliography}

Bibliography contains references to reading material that are relevant to the text material of the observation report in the assessment instrument. The results of the research material character-based assessment instruments for class $\mathrm{X}$ high school that were submitted through a questionnaire method with a questionnaire instrument presented descriptively.

The material validator for the instrument developed was intended to find out the material expert's opinion about the feasibility of content, the feasibility of presentation and the feasibility of language. This validation was carried out by 2 UNIMED lecturers, namely; 1. Dr. Safwan Hadi Umri, M.Pd. 2. Dr Elly Prihasti Wuriyani, SS, M.Pd. Data from material expert validation on content eligibility can be seen in the table below

Table 6. The Results of the Validation of the Content of the Character-based Assessment Instrument

\begin{tabular}{|c|c|c|c|c|c|c|}
\hline \multirow{2}{*}{ Sub Components } & \multirow{2}{*}{ Indicator } & \multicolumn{2}{|c|}{ Respondents } & \multirow{2}{*}{$\begin{array}{c}\text { amount } \\
\text { Sk } \\
\text { or }\end{array}$} & \multirow{2}{*}{ Average } & \multirow{2}{*}{$\begin{array}{l}\text { Criter } \\
\text { ia }\end{array}$} \\
\hline & & $\mathbf{1}$ & 2 & & & \\
\hline \multirow[t]{2}{*}{$\begin{array}{l}\text { A. Suitability } \\
\text { of material } \\
\text { with KI and } \\
\text { KD }\end{array}$} & $\begin{array}{l}\text { 1.Completene } \\
\text { ss of the } \\
\text { material }\end{array}$ & 5 & 4 & 9 & $90 \%$ & $\begin{array}{l}\text { Very } \\
\text { good }\end{array}$ \\
\hline & $\begin{array}{l}\text { 2. Depth of } \\
\text { Material }\end{array}$ & 4 & 4 & 8 & $80 \%$ & Good \\
\hline \multirow[t]{3}{*}{$\begin{array}{l}\text { B. Strength of } \\
\text { Matter }\end{array}$} & $\begin{array}{l}\text { 3. Accuracy of } \\
\text { concepts and } \\
\text { definitions }\end{array}$ & 5 & 4 & 9 & $90 \%$ & $\begin{array}{l}\text { Very } \\
\text { good }\end{array}$ \\
\hline & $\begin{array}{l}\text { 4. Accuracy of } \\
\text { facts and data }\end{array}$ & 4 & 4 & 8 & $80 \%$ & Good \\
\hline & 5. Accuracy of & & & & & \\
\hline
\end{tabular}




\begin{tabular}{|c|c|c|c|c|c|c|}
\hline & $\begin{array}{l}\text { examples and } \\
\text { cases }\end{array}$ & 5 & 4 & 8 & $80 \%$ & Good \\
\hline & $\begin{array}{l}\text { 6. The } \\
\text { accuracy of } \\
\text { pictures, } \\
\text { diagrams and } \\
\text { illustrations of } \\
\text { learning to } \\
\text { write poetry }\end{array}$ & 4 & 3 & 7 & $70 \%$ & Good \\
\hline \multirow{7}{*}{$\begin{array}{l}\text { C. Material } \\
\text { Proficiency }\end{array}$} & $\begin{array}{l}\text { 7. Accuracy of } \\
\text { terms }\end{array}$ & 4 & 4 & 8 & $80 \%$ & Good \\
\hline & $\begin{array}{l}\text { 8. Accuracy of } \\
\text { notations, } \\
\text { symbols and } \\
\text { icons }\end{array}$ & 4 & 4 & 8 & $80 \%$ & Good \\
\hline & $\begin{array}{l}\text { 9. Reference } \\
\text { accuracy }\end{array}$ & 4 & 4 & 8 & $80 \%$ & Good \\
\hline & $\begin{array}{l}\text { 10. Suitability } \\
\text { of the material } \\
\text { with the } \\
\text { development } \\
\text { of science }\end{array}$ & 5 & 4 & 9 & $90 \%$ & Good \\
\hline & $\begin{array}{l}\text { 11. Using case } \\
\text { examples in } \\
\text { everyday life }\end{array}$ & 5 & 3 & 8 & $80 \%$ & Good \\
\hline & $\begin{array}{l}\text { 12. Pictures, } \\
\text { diagrams and } \\
\text { illustrations in } \\
\text { everyday life }\end{array}$ & 4 & 3 & 7 & $70 \%$ & Good \\
\hline & $\begin{array}{l}\text { 13. Using } \\
\text { examples of } \\
\text { cases found in } \\
\text { everyday life }\end{array}$ & 4 & 4 & 8 & $80 \%$ & Good \\
\hline \multirow{3}{*}{$\begin{array}{l}\text { D. Encourages } \\
\text { Curiosity }\end{array}$} & $\begin{array}{l}\text { 14. Up-to-date } \\
\text { library }\end{array}$ & 4 & 4 & 8 & $80 \%$ & Good \\
\hline & $\begin{array}{l}15 . \text { Encourage } \\
\text { curiosity }\end{array}$ & 5 & 4 & 9 & $90 \%$ & $\begin{array}{l}\text { Very } \\
\text { good }\end{array}$ \\
\hline & $\begin{array}{l}\text { 16. questioning } \\
\text { ability }\end{array}$ & 4 & 4 & 8 & $80 \%$ & Good \\
\hline \multicolumn{2}{|c|}{ TOTAL } & \multicolumn{2}{|c|}{7061} & 131 & $81.88 \%$ & Good \\
\hline \multicolumn{2}{|c|}{ Validation Results } & \multicolumn{2}{|c|}{$81.88 \%$} & & & $\begin{array}{l}\text { Very } \\
\text { Valid }\end{array}$ \\
\hline
\end{tabular}


Based on the results of the validation by material experts on the character-based assessment instrument developed, the scores of validators 1 and 2 were 131 with a percentage of $81.88 \%$. The percentage is obtained from the calculation:

$$
\text { Percentage }=\frac{131}{16 \times 10} \times 100 \%=81,88 \%
$$

The percentage of the eligibility score for the contents of the assessment instrument by validators 1 and 2 on the qualification is very valid. So that the character-based assessment instrument in the developed poetry writing material does not need to be revised. Feasibility of the content is suitable for use.

Table 7. Revised List of Material Experts

\begin{tabular}{|c|l|}
\hline Validation Aspects & \multicolumn{1}{|c|}{ Revision } \\
\hline \multirow{2}{*}{ Theory } & $\begin{array}{l}\text { 1. Complete the table of contents and } \\
\text { bibliography }\end{array}$ \\
\cline { 2 - 2 } & $\begin{array}{l}\text { 2. Need to improve spelling and } \\
\text { diction }\end{array}$ \\
\hline
\end{tabular}

All comments and suggestions given by the validator are taken into consideration in making revisions to the character-based assessment instrument developed.

Table 8. The Results of Feasibility Validation in Presenting a Character-Based Assessment Instrument

\begin{tabular}{|c|c|c|c|c|c|c|}
\hline \multirow{2}{*}{$\begin{array}{c}\text { Sub } \\
\text { Components }\end{array}$} & \multirow{2}{*}{$\begin{array}{l}\text { Assessment } \\
\text { Indicators }\end{array}$} & \multicolumn{2}{|c|}{ Validator } & \multirow{2}{*}{$\begin{array}{l}\text { Total } \\
\text { Score } \\
\end{array}$} & \multirow[t]{2}{*}{ Average } & \multirow[t]{2}{*}{ Criteria } \\
\hline & & 1 & 2 & & & \\
\hline \multirow[t]{2}{*}{$\begin{array}{l}\text { A. Presentatio } \\
\mathrm{n} \\
\text { Technique }\end{array}$} & 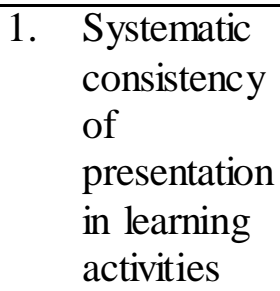 & 4 & 4 & 8 & $80 \%$ & Good \\
\hline & $\begin{array}{ll}\text { 2. } & \begin{array}{l}\text { Concept } \\
\text { clutter }\end{array} \\
\end{array}$ & 4 & 4 & 8 & $80 \%$ & Good \\
\hline \multirow{3}{*}{$\begin{array}{l}\text { B. Presentatio } \\
n \text { of } \\
\text { Learning }\end{array}$} & $\begin{array}{ll}3 . & \begin{array}{l}\text { Student } \\
\text { involvement }\end{array}\end{array}$ & 4 & 3 & 7 & $70 \%$ & Good \\
\hline & 4. $\quad$ Learning & 4 & 3 & 7 & $70 \%$ & Good \\
\hline & $\begin{array}{l}\text { 5. } \\
\text { Stimulate } \\
\text { students' } \\
\text { ability to } \\
\text { solve } \\
\text { problems } \\
\text { through } \\
\text { illustrations }\end{array}$ & 5 & 4 & 9 & $90 \%$ & $\begin{array}{l}\text { Very } \\
\text { good }\end{array}$ \\
\hline
\end{tabular}




\begin{tabular}{|c|c|c|c|c|c|c|}
\hline \multirow[t]{6}{*}{$\begin{array}{l}\text { C. Completens } \\
\text { of Serving }\end{array}$} & $\begin{array}{l}\text { 6. Text quotes } \\
\text { or stories in } \\
\text { each } \\
\text { learning } \\
\text { activity }\end{array}$ & 5 & 4 & 9 & $90 \%$ & $\begin{array}{l}\text { Very } \\
\text { good }\end{array}$ \\
\hline & $\begin{array}{l}\text { 7. The answer } \\
\text { key to the } \\
\text { question }\end{array}$ & 4 & 5 & 9 & $90 \%$ & $\begin{array}{l}\text { Very } \\
\text { good }\end{array}$ \\
\hline & 8. Introduction & 4 & 5 & 9 & $90 \%$ & $\begin{array}{l}\text { Very } \\
\text { good }\end{array}$ \\
\hline & $\begin{array}{l}\text { 9. table of } \\
\text { contents }\end{array}$ & 4 & 5 & 9 & $90 \%$ & $\begin{array}{l}\text { Very } \\
\text { good }\end{array}$ \\
\hline & 10. Glossary & 4 & 5 & 9 & $90 \%$ & $\begin{array}{l}\text { Very } \\
\text { good }\end{array}$ \\
\hline & 11. Bibliography & 4 & 4 & 8 & $80 \%$ & Good \\
\hline \multicolumn{2}{|c|}{ TOTAL } & $\overline{46}$ & 46 & 92 & $83.63 \%$ & $\begin{array}{l}\text { Very } \\
\text { good }\end{array}$ \\
\hline \multicolumn{2}{|c|}{ VALIDATION RESULTS } & \multicolumn{2}{|c|}{$83.63 \%$} & & \multicolumn{2}{|c|}{ Very Valid } \\
\hline
\end{tabular}

Based on the results of the presentation from the material expert about the feasibility of the presentation above, an average score of $83.63 \%$ was obtained with the criteria "very good" so that the character-based assessment instrument as a whole shows in the "very valid" category.

Table 9. The Feasibility Validation Results of the Character-Based Assessment Instrument Language

\begin{tabular}{|c|c|c|c|c|c|c|}
\hline \multirow{2}{*}{ Sub Components } & \multirow{2}{*}{$\begin{array}{l}\text { Assessment } \\
\text { Indicators }\end{array}$} & \multicolumn{2}{|c|}{ Validator } & \multirow{2}{*}{$\begin{array}{l}\text { Total } \\
\text { Score } \\
\end{array}$} & \multirow[t]{2}{*}{ Average } & \multirow[t]{2}{*}{ Criteria } \\
\hline & & 1 & 2 & & & \\
\hline \multirow[t]{3}{*}{ a.Straightforward } & $\begin{array}{l}\text { 1. Sentence } \\
\text { accuracy }\end{array}$ & 4 & 4 & 8 & $80 \%$ & Good \\
\hline & $\begin{array}{l}\text { 2. The } \\
\text { effectiveness } \\
\text { of sentences }\end{array}$ & 4 & 4 & 8 & $80 \%$ & Good \\
\hline & $\begin{array}{l}\text { 3. Rigor of the } \\
\text { term }\end{array}$ & 4 & 4 & 8 & $80 \%$ & Good \\
\hline \multirow[t]{2}{*}{ b.Communicative } & $\begin{array}{l}\text { 4. Message } \\
\text { readability }\end{array}$ & 4 & 4 & 8 & $80 \%$ & Good \\
\hline & $\begin{array}{l}\text { 5. The } \\
\text { accuracy of } \\
\text { using the } \\
\text { language }\end{array}$ & 4 & 4 & 8 & $80 \%$ & Good \\
\hline $\begin{array}{l}\text { C. Dialogical and } \\
\text { instructive }\end{array}$ & $\begin{array}{l}\text { 6. The ability } \\
\text { to motivate } \\
\text { messages or } \\
\text { information }\end{array}$ & 4 & 4 & 8 & $80 \%$ & Good \\
\hline
\end{tabular}




\begin{tabular}{|c|c|c|c|c|c|c|}
\hline & $\begin{array}{l}\text { 7. Ability to } \\
\text { encourage } \\
\text { higher } \\
\text { thinking }\end{array}$ & 4 & 3 & 7 & $70 \%$ & Good \\
\hline \multirow[t]{2}{*}{$\begin{array}{l}\text { D. Suitability to } \\
\text { the level of } \\
\text { student } \\
\text { development }\end{array}$} & $\begin{array}{l}\text { 8. The } \\
\text { suitability of } \\
\text { students' } \\
\text { intellectual } \\
\text { development }\end{array}$ & 4 & 4 & 8 & $80 \%$ & Good \\
\hline & $\begin{array}{l}\text { 9. Conformity } \\
\text { with the level } \\
\text { of student } \\
\text { emotional } \\
\text { development }\end{array}$ & 4 & 3 & 7 & $70 \%$ & Good \\
\hline \multirow[t]{2}{*}{$\begin{array}{l}\text { E. Cluster and } \\
\text { coherent flow of } \\
\text { thought }\end{array}$} & $\begin{array}{l}\text { 10. Cluster } \\
\text { and } \\
\text { cohesiveness } \\
\text { between } \\
\text { learning } \\
\text { activities }\end{array}$ & 4 & 3 & 7 & $70 \%$ & Good \\
\hline & $\begin{array}{l}\text { 11. Cluster } \\
\text { and } \\
\text { cohesiveness } \\
\text { between } \\
\text { paragraphs }\end{array}$ & 4 & 4 & 8 & $80 \%$ & Good \\
\hline \multirow{2}{*}{$\begin{array}{l}\text { F. Use of the } \\
\text { terms symbols } \\
\text { and icons }\end{array}$} & $\begin{array}{l}\text { 12. Consistent } \\
\text { use of terms }\end{array}$ & 4 & 3 & 7 & $70 \%$ & Good \\
\hline & $\begin{array}{l}\text { 13. Consistent } \\
\text { use of } \\
\text { symbols and } \\
\text { icons. }\end{array}$ & 4 & 4 & 8 & $80 \%$ & Good \\
\hline \multicolumn{2}{|c|}{ TOTAL } & 52 & 48 & 100 & $76.92 \%$ & Good \\
\hline \multicolumn{2}{|c|}{ VALIDATION RESULTS } & \multicolumn{2}{|c|}{$76.92 \%$} & & \multicolumn{2}{|c|}{ Valid } \\
\hline
\end{tabular}

Based on the results of the presentation from the material expert about the feasibility of the language above, an average score of $76.92 \%$ was obtained with the criteria "good" so that this character-based assessment instrument as a whole shows in the "valid" category.

Based on the data above, the material validation in terms of the feasibility of content, presentation and language resulted in an assessment of $80.81 \%$. The assessment belongs to the very valid category.

Table 10. The Results of the Validation of the Multiple Choice Assessment Instrument Based on Character-based Poetry Material

\begin{tabular}{|c|c|c|c|l|l|l|}
\hline \multirow{3}{*}{ Aspect } & \multirow{2}{*}{$\begin{array}{c}\text { Assessment } \\
\text { Indicators }\end{array}$} & \multicolumn{2}{|c|}{ Validator } & $\begin{array}{l}\text { Total } \\
\text { Score }\end{array}$ & Average & Criteria \\
\cline { 3 - 7 } & & 1 & 2 & & & \\
\hline
\end{tabular}




\begin{tabular}{|c|c|c|c|c|c|c|}
\hline \multirow[t]{7}{*}{ Theory } & $\begin{array}{l}\text { Questions } \\
\text { according to Basic } \\
\text { Competencies }\end{array}$ & 5 & 5 & 10 & $100 \%$ & $\begin{array}{l}\text { Very } \\
\text { good }\end{array}$ \\
\hline & $\begin{array}{l}\text { The question does } \\
\text { not contain } \\
\text { elements of } \\
\text { SARAPPPK } \\
\text { (ethnicity, religion, } \\
\text { race, intergroup, } \\
\text { pornography, } \\
\text { politics, } \\
\text { propaganda, and } \\
\text { violence) }\end{array}$ & 5 & 4 & 9 & $90 \%$ & $\begin{array}{l}\text { Very } \\
\text { good }\end{array}$ \\
\hline & $\begin{array}{l}\text { Problem using } \\
\text { interesting stimuli } \\
\text { (new, encouraging } \\
\text { students to read) }\end{array}$ & 4 & 3 & 7 & $70 \%$ & Good \\
\hline & $\begin{array}{l}\text { Problems using } \\
\text { contextual stimuli } \\
\text { (images / graphics, } \\
\text { text, visualization, } \\
\text { etc., according to } \\
\text { the real world) }\end{array}$ & 4 & 4 & 8 & $80 \%$ & Good \\
\hline & $\begin{array}{l}\text { The answer is } \\
\text { implied to the } \\
\text { stimulus }\end{array}$ & 4 & 4 & 8 & $80 \%$ & Good \\
\hline & $\begin{array}{l}\text { Homogeneous and } \\
\text { logical answer } \\
\text { choices }\end{array}$ & 4 & 4 & 8 & $80 \%$ & Good \\
\hline & $\begin{array}{l}\text { Each question has } \\
\text { only one correct } \\
\text { answer }\end{array}$ & 4 & 4 & 8 & $80 \%$ & Good \\
\hline & $\begin{array}{l}\text { The subject matter } \\
\text { is formulated } \\
\text { briefly, clearly, and } \\
\text { firmly. }\end{array}$ & 4 & 4 & 8 & $80 \%$ & Good \\
\hline & $\begin{array}{l}\text { The formulation of } \\
\text { the subject matter } \\
\text { and the choice of } \\
\text { answers are just } \\
\text { statements that are } \\
\text { needed. }\end{array}$ & 4 & 4 & 8 & $80 \%$ & Good \\
\hline & $\begin{array}{l}\text { The subject matter } \\
\text { does not provide a } \\
\text { clue to the answer } \\
\text { key. }\end{array}$ & 4 & 4 & 8 & $80 \%$ & Good \\
\hline & $\begin{array}{l}\text { The subject matter } \\
\text { is free from }\end{array}$ & 4 & 4 & 8 & $80 \%$ & Good \\
\hline
\end{tabular}




\begin{tabular}{|c|c|c|c|c|c|c|}
\hline & $\begin{array}{l}\text { statements that are } \\
\text { double negative. }\end{array}$ & & & & & \\
\hline & $\begin{array}{l}\text { Pictures, graphs, } \\
\text { tables, diagrams, or } \\
\text { the like are clear } \\
\text { and functional. }\end{array}$ & 4 & 4 & 8 & $80 \%$ & Good \\
\hline & $\begin{array}{l}\text { The length of the } \\
\text { answer choices is } \\
\text { relatively the same }\end{array}$ & 4 & 4 & 8 & $80 \%$ & Good \\
\hline & $\begin{array}{l}\text { The answer choices } \\
\text { do not use the } \\
\text { statement "all the } \\
\text { above answers are } \\
\text { wrong" or "all the } \\
\text { answers above are } \\
\text { correct" and the } \\
\text { like. }\end{array}$ & 4 & 5 & 9 & $90 \%$ & $\begin{array}{l}\text { Very } \\
\text { good }\end{array}$ \\
\hline & $\begin{array}{l}\text { The answer choices } \\
\text { in the form of } \\
\text { numbers / time are } \\
\text { arranged according } \\
\text { to the order of the } \\
\text { size of the numbers } \\
\text { or chronology. }\end{array}$ & 4 & 4 & 8 & $80 \%$ & Good \\
\hline & $\begin{array}{l}\text { The items do not } \\
\text { depend on the } \\
\text { answers to other } \\
\text { questions. }\end{array}$ & 4 & 3 & 7 & $70 \%$ & Good \\
\hline Language & $\begin{array}{l}\text { Use language that is } \\
\text { in accordance with } \\
\text { the rules of } \\
\text { Indonesian in } \\
\text { PUEBI. }\end{array}$ & 4 & 5 & 9 & $90 \%$ & $\begin{array}{l}\text { Very } \\
\text { good }\end{array}$ \\
\hline & $\begin{array}{l}\text { Do not use local } \\
\text { language / taboo }\end{array}$ & 4 & 5 & 9 & $90 \%$ & $\begin{array}{l}\text { Very } \\
\text { good }\end{array}$ \\
\hline & $\begin{array}{l}\text { Problem using } \\
\text { communicative } \\
\text { sentences. }\end{array}$ & 4 & 4 & 8 & $80 \%$ & Good \\
\hline & $\begin{array}{l}\text { The answer choices } \\
\text { do not repeat the } \\
\text { same word group of } \\
\text { words, unless they } \\
\text { constitute one } \\
\text { unified meaning }\end{array}$ & 4 & 4 & 8 & $80 \%$ & Good \\
\hline & $\mathrm{TAL}$ & 84 & 78 & 162 & $81 . \%$ & $\begin{array}{l}\text { Very } \\
\text { Good }\end{array}$ \\
\hline VALID & ON RESULTS & & & & & alid \\
\hline
\end{tabular}


Based on the results of the validation of the two experts on the Multiple Choice assessment instrument developed as a whole, it can be declared very valid. From the two validation results given by validator 1 and validator 2 , the score was 162 with a percentage of $81 \%$. The percentage is obtained from the calculation:

$$
\text { Percentage }=\frac{162}{20 \times 10} \times 100 \%=81 \%
$$

Table 11. Results of Validation by Experts Evaluation of Multiple Choice Questions

\begin{tabular}{|c|c|c|c|}
\hline No. & $\begin{array}{c}\text { Material Expert Validation } \\
\text { Team }\end{array}$ & Score & Percentage \\
\hline $\mathbf{1}$ & Validator 1 & 84 & $84 \%$ \\
\hline $\mathbf{2}$ & Vaidator 2 & 78 & $78 \%$ \\
\hline \multicolumn{2}{|c|}{ amount } & $\mathbf{1 6 2}$ & $\mathbf{8 1 \%}$ \\
\hline
\end{tabular}

Table 12. The Results of the Validation of the Character-based Description of the Poetry Material Assessment Instrument

\begin{tabular}{|c|l|c|c|c|c|c|}
\hline \multirow{2}{*}{ Aspect } & \multicolumn{2}{|c|}{ Validator } & \multicolumn{1}{|c|}{$\begin{array}{c}\text { Total } \\
\text { Score }\end{array}$} & Average & Criteria \\
\cline { 2 - 7 } Theory & Assessment Indicators & $\mathbf{1}$ & $\mathbf{2}$ & & & \\
\hline & $\begin{array}{l}\text { Questions in } \\
\text { accordance with Basic } \\
\text { Competencies (requires } \\
\text { a written test in the } \\
\text { form of a description) }\end{array}$ & 5 & 4 & 90 & $90 \%$ & Very good \\
\cline { 2 - 7 } & $\begin{array}{l}\text { The question does not } \\
\text { contain elements of } \\
\text { SARAPPPK (ethnicity, } \\
\text { religion, race, } \\
\text { intergroup, } \\
\text { pornography, politics, } \\
\text { propaganda, and } \\
\text { violence) }\end{array}$ & 5 & 4 & 9 & $90 \%$ & Very good \\
\cline { 2 - 7 } & $\begin{array}{l}\text { Problem using } \\
\text { interesting stimuli } \\
\text { (new, encouraging } \\
\text { students to read) }\end{array}$ & 4 & 4 & 7 & $70 \%$ & Good \\
\hline $\begin{array}{l}\text { Problems using } \\
\text { contextual stimuli } \\
\text { (images / graphics, text, } \\
\text { visualization, etc., } \\
\text { according to the real } \\
\text { world) }\end{array}$ & $\begin{array}{l}\text { The problem measures } \\
\text { the cognitive level of }\end{array}$ & 4 & 4 & 8 & $70 \%$ & Good \\
\hline
\end{tabular}




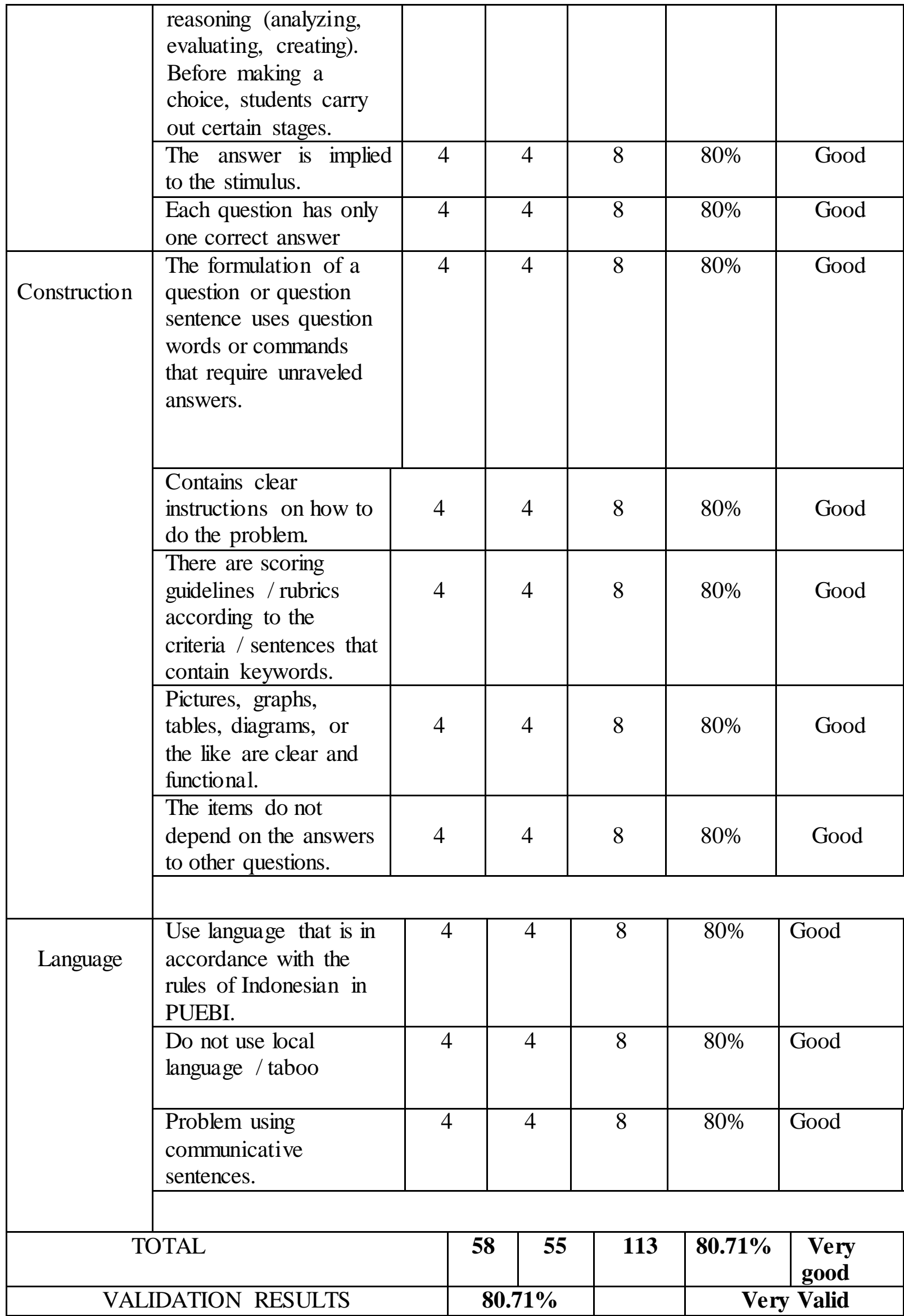


Based on the results of the validation of the two experts on the assessment instrument developed as a whole it can be declared very valid. From the two validation results given by validator 1 and validator 2, the score was 113 with a percentage of $80.71 \%$. The percentage is obtained from the calculation:

$$
\text { Percentage }=\frac{113}{14 \times 10} \times 100 \%=80,71 \%
$$

Based on the results of the evaluation expert's assessment on multiple choice questions and the description, the average percentage was $80.85 \%$ and were in very valid qualifications, this meant that the questions did not need to be corrected. In addition to grading, experts also provide input in the form of comments and suggestions related to the aspects assessed in the character-based assessment instrument. The following is a description of the things that need to be revised in the character-based poetry assessment instrument provided by the evaluation expert.

Table 13. Revised List of Evaluation Experts

\begin{tabular}{|c|c|}
\hline Validation Aspects & \multicolumn{1}{|c|}{ Revision } \\
\hline \multirow{2}{*}{ Evaluation } & \begin{tabular}{l} 
1. $\begin{array}{l}\text { Correct any errors in writing the words } \\
\text { on the assessment instrument. }\end{array}$ \\
\cline { 2 - 3 }
\end{tabular} \\
$\begin{array}{l}2 . \\
\text { The items of character-based poetry } \\
\text { assessment should be added }\end{array}$ \\
\hline
\end{tabular}

All comments and suggestions given by the validator are taken into consideration in making revisions to the character-based assessment instrument developed.

Descriptive exposure of the results of the assessment of Indonesian learning experts (teachers) on the development of assessment instruments through the questionnaire method with the questionnaire instrument will be presented below. Based on the teacher's assessment of the character-based poetry assessment instrument developed, the percentage score was $89.33 \%$. The percentage is obtained from the calculation:

$$
\text { Percentage }=\frac{67}{15 \times 5} \times 100=89,33 \%
$$

Based on the results of the teacher's assessment of the assessment instrument, the total score was 67 with a percentage of $89.33 \%$ and was in a very valid qualification, this means that the assessment instrument does not need to be improved. In addition to grading, the teacher also provides comments and suggestions related to the aspects assessed in the character-based assessment instrument. The following is a description of the things that need to be revised in the assessment instrument provided by the teacher.

Table 14. Questionnaire Suggestions for Practicality of Assessment Instruments

\begin{tabular}{|c|l|}
\hline \multicolumn{1}{|c|}{ Validator Name } & \multicolumn{1}{|c|}{ Criticism and Suggestions } \\
\hline Henni Indriani Lubis, S.Pd & $\begin{array}{l}\text { 1. The details of the questions should be made more } \\
\text { clear } \\
\text { 2. Corrected word typing errors, pay attention to } \\
\text { punctuation marks (period / comma). }\end{array}$ \\
\hline
\end{tabular}


After the initial product development stage has been carried out and revised by the previous validator, the next stage to be carried out is a field test on an individual scale. By involving as many as 3 students in class X SMA Negeri 3 Medan. In this step, the revised assessment instrument in revision $\mathrm{I}$ and an individual assessment questionnaire is given. This trial aims to determine whether the development of character-based poetry learning assessment instruments is appropriate for use in the subsequent assessment process.

Table 15. Percentage of Individual Trials

\begin{tabular}{|c|c|c|c|c|c|c|c|c|c|c|c|c|c|c|}
\hline \multirow{2}{*}{$\begin{array}{c}\text { No. } \\
\text { Sort }\end{array}$} & \multicolumn{9}{|c|}{ Frequency } & \multicolumn{7}{c|}{} & \multirow{2}{*}{ Criteria } \\
\cline { 2 - 13 } & $\mathbf{5}$ & $\mathbf{4}$ & $\mathbf{3}$ & $\mathbf{2}$ & $\mathbf{1}$ & Total & $\mathbf{5}$ & $\mathbf{4}$ & $\mathbf{3}$ & $\mathbf{2}$ & $\mathbf{1}$ & Total & $\%$ & \\
\hline $\mathbf{1}$ & 5 & 7 & 0 & 0 & 0 & 12 & 25 & 28 & 0 & 0 & 0 & 53 & $\mathbf{8 8 . 3 3 \%}$ & $\begin{array}{c}\text { Very } \\
\text { good }\end{array}$ \\
\hline $\mathbf{2}$ & 8 & 4 & 0 & 0 & 0 & 12 & 40 & 16 & 0 & 0 & 0 & 56 & $\mathbf{9 3 . 3 3 \%}$ & $\begin{array}{c}\text { Very } \\
\text { good }\end{array}$ \\
\hline $\mathbf{3}$ & 8 & 4 & 0 & 0 & 0 & 12 & 40 & 16 & 0 & 0 & 0 & 56 & $\mathbf{9 3 . 3 3 \%}$ & $\begin{array}{c}\text { Very } \\
\text { good }\end{array}$ \\
\hline amount & $\mathbf{2 1}$ & $\mathbf{1 5}$ & $\mathbf{0}$ & $\mathbf{0}$ & $\mathbf{0}$ & $\mathbf{1 2}$ & $\mathbf{1 0 5}$ & $\mathbf{6 0}$ & $\mathbf{0}$ & $\mathbf{0}$ & $\mathbf{0}$ & $\mathbf{1 6 5}$ & $\mathbf{9 1 . 6 6 \%}$ & $\begin{array}{c}\text { Very } \\
\text { good }\end{array}$ \\
\hline
\end{tabular}

Based on the table above, it shows the average percentage of the assessment results on the individual trial of the character-based poetry assessment instrument of $91.66 \%$, which is in the very good category. Based on the results of the assessment on the poetry text material, individual trials do not need improvement.

Table 16. Percentage of Small Group Trials

\begin{tabular}{|c|c|c|c|c|c|c|c|c|c|c|c|c|c|c|}
\hline \multirow{2}{*}{$\begin{array}{l}\text { No. } \\
\text { Sort }\end{array}$} & \multicolumn{6}{|c|}{ Frequency } & \multicolumn{7}{|c|}{ Score } & \multirow{2}{*}{ Criteria } \\
\hline & 5 & 4 & 3 & 2 & 1 & Total & 5 & 4 & 3 & 2 & 1 & Total & $\%$ & \\
\hline 1 & 9 & 3 & 0 & 0 & 0 & 12 & 45 & 12 & 0 & 0 & 0 & 57 & $95 \%$ & $\begin{array}{l}\text { Very } \\
\text { good }\end{array}$ \\
\hline 2 & 8 & 4 & 0 & 0 & 0 & 12 & 40 & 16 & 0 & 0 & 0 & 56 & $93.33 \%$ & $\begin{array}{l}\text { Very } \\
\text { good }\end{array}$ \\
\hline 3 & 7 & 3 & 2 & 0 & 0 & 12 & 35 & 12 & 6 & 0 & 0 & 53 & $88.33 \%$ & $\begin{array}{l}\text { Very } \\
\text { good }\end{array}$ \\
\hline 4 & 4 & 8 & 0 & 0 & 0 & 12 & 20 & 32 & 0 & 0 & 0 & 52 & $86.66 \%$ & $\begin{array}{l}\text { Very } \\
\text { good }\end{array}$ \\
\hline 5 & 7 & 5 & 0 & 0 & 0 & 12 & 35 & 20 & 0 & 0 & 0 & 55 & $91.66 \%$ & $\begin{array}{l}\text { Very } \\
\text { good }\end{array}$ \\
\hline 6 & 9 & 3 & 0 & 0 & 0 & 12 & 45 & 12 & 0 & 0 & 0 & 57 & $95 \%$ & $\begin{array}{l}\text { Very } \\
\text { good }\end{array}$ \\
\hline 7 & 8 & 3 & 1 & 0 & 0 & 12 & 40 & 12 & 3 & 0 & 0 & 55 & $91.66 \%$ & $\begin{array}{l}\text { Very } \\
\text { good }\end{array}$ \\
\hline 8 & 7 & 5 & 0 & 0 & 0 & 12 & 35 & 20 & 0 & 0 & 0 & 55 & $91.66 \%$ & $\begin{array}{l}\text { Very } \\
\text { good }\end{array}$ \\
\hline 9 & 3 & 7 & 1 & 0 & 1 & 12 & 15 & 28 & 0 & 0 & 1 & 44 & $73.33 \%$ & Good \\
\hline Total & 52 & 38 & 13 & 3 & 52 & 12 & 260 & 152 & 39 & 6 & 0 & 484 & $89.62 \%$ & $\begin{array}{l}\text { Very } \\
\text { good }\end{array}$ \\
\hline
\end{tabular}


Based on the table above, it shows the average percentage of the results of the assessment in the group trial of the character-based assessment instrument of $89.62 \%$, including the very good category. Based on the results of this assessment, the poetry text material belongs to the very good category, but there are several things that are evaluated, namely additional explanations by the teacher need to be done to help students better understand.

Table 17. Percentage of KD Field Trials

\begin{tabular}{|c|c|c|c|}
\hline \multirow{2}{*}{$\begin{array}{c}\text { Serial } \\
\text { number }\end{array}$} & \multicolumn{2}{|c|}{ Score } & \multirow{2}{*}{ Criteria } \\
\hline & Total & Percentage & \\
\hline 1 & 249 & $83 \%$ & SB \\
\hline 2 & 240 & $80 \%$ & $\mathrm{~B}$ \\
\hline 3 & 238 & $79.3 \%$ & B \\
\hline 4 & 238 & $79 \%$ & B \\
\hline 5 & 253 & $84.3 \%$ & SB \\
\hline 6 & 238 & 79.3 & $\mathrm{~B}$ \\
\hline 7 & 236 & $78.7 \%$ & $\bar{B}$ \\
\hline 8 & 252 & $84 \%$ & SB \\
\hline 9 & 192 & $64 \%$ & $\mathrm{~B}$ \\
\hline 10 & 217 & 72.3 & B \\
\hline 11 & 248 & $82.7 \%$ & $\overline{\text { SB }}$ \\
\hline 12 & 229 & $76.3 \%$ & $\mathrm{~B}$ \\
\hline 13 & 248 & $82.7 \%$ & SB \\
\hline 14 & 244 & $81.3 \%$ & SB \\
\hline 15 & 242 & $80.7 \%$ & SB \\
\hline 16 & 238 & $79.3 \%$ & $\mathrm{~B}$ \\
\hline 17 & 206 & $68.7 \%$ & B \\
\hline 18 & 257 & $85.7 \%$ & SB \\
\hline 19 & 247 & $82.3 \%$ & SB \\
\hline 20 & 248 & $82.7 \%$ & SB \\
\hline 21 & 197 & $65.7 \%$ & $\mathrm{~B}$ \\
\hline 22 & 225 & $75 \%$ & B \\
\hline 23 & 226 & $75.3 \%$ & B \\
\hline 24 & 265 & $88.3 \%$ & SB \\
\hline 25 & 203 & $67.7 \%$ & $\mathrm{~B}$ \\
\hline 26 & 210 & $70 \%$ & B \\
\hline 27 & 227 & $75.6 \%$ & B \\
\hline 28 & 225 & $75 \%$ & B \\
\hline 29 & 243 & $81 \%$ & SB \\
\hline 30 & 218 & $72.7 \%$ & $\mathrm{~B}$ \\
\hline 31 & 187 & $62.3 \%$ & B \\
\hline 32 & 206 & $68.7 \%$ & B \\
\hline 33 & 212 & 70.7 & B \\
\hline \multicolumn{2}{|c|}{ Total } & 76.54 & B \\
\hline
\end{tabular}


Table 18. Percentage of KD Field

\begin{tabular}{|c|c|c|c|}
\hline \multirow{2}{*}{$\begin{array}{c}\text { Serial } \\
\text { number }\end{array}$} & \multicolumn{2}{|c|}{ Score } & \multirow{2}{*}{ Criteria } \\
\hline & Total & Percentage & \\
\hline 1 & 239 & $79.7 \%$ & $\mathrm{~B}$ \\
\hline 2 & 239 & $79.7 \%$ & B \\
\hline 3 & 223 & $74.3 \%$ & B \\
\hline 4 & 229 & $76.3 \%$ & B \\
\hline 5 & 244 & $81.3 \%$ & B \\
\hline 6 & 224 & $74.7 \%$ & B \\
\hline 7 & 220 & $73.3 \%$ & $\mathrm{~B}$ \\
\hline 8 & 243 & $81 \%$ & $\mathrm{~B}$ \\
\hline 9 & 214 & $71.3 \%$ & B \\
\hline 10 & 226 & $75.3 \%$ & B \\
\hline 11 & 240 & $80 \%$ & B \\
\hline 12 & 225 & $75 \%$ & $\mathrm{~B}$ \\
\hline 13 & 242 & $80.7 \%$ & SB \\
\hline 14 & 241 & $80.3 \%$ & SB \\
\hline 15 & 228 & $76 \%$ & $\mathrm{~B}$ \\
\hline 16 & 229 & $76.3 \%$ & $\mathrm{~B}$ \\
\hline 17 & 220 & $73.3 \%$ & $\mathrm{~B}$ \\
\hline 18 & 251 & $83.7 \%$ & SB \\
\hline 19 & 240 & $80 \%$ & $\mathrm{~B}$ \\
\hline 20 & 246 & $82 \%$ & SB \\
\hline 21 & 210 & $70 \%$ & $\mathrm{~B}$ \\
\hline 22 & 226 & $75.3 \%$ & $\mathrm{~B}$ \\
\hline 23 & 233 & $77.7 \%$ & $\mathrm{~B}$ \\
\hline 24 & 245 & $81.7 \%$ & SB \\
\hline 25 & 212 & $70.6 \%$ & $\mathrm{~B}$ \\
\hline 26 & 220 & $73.3 \%$ & $\mathrm{~B}$ \\
\hline 27 & 228 & $76 \%$ & B \\
\hline 28 & 228 & $76 \%$ & B \\
\hline 29 & 238 & $79.3 \%$ & B \\
\hline 30 & 231 & $77 \%$ & B \\
\hline 31 & 208 & $69.3 \%$ & B \\
\hline 32 & 211 & $70.3 \%$ & B \\
\hline 33 & 224 & $74.7 \%$ & $\mathrm{~B}$ \\
\hline \multicolumn{2}{|c|}{ Total } & $76.37 \%$ & $\mathrm{~B}$ \\
\hline
\end{tabular}

Table 19. Average Student Attitude Assessment Test

\begin{tabular}{|c|c|c|}
\hline No. & Assessment test & Percentage \\
\hline 1 & Activity 1 & $76.54 \%$ \\
\hline 2 & Activity 2 & $76.37 \%$ \\
\hline \multicolumn{2}{|c|}{ Total } & $\mathbf{7 6 . 4 6 \%}$ \\
\hline
\end{tabular}


In the field trial phase the researcher tested the level of students' understanding ability to see the level of effectiveness of the assessment instrument. Akker (1999: 10) states that "effectiveness refers to the extent of experience and results with the intended objectives". Based on the results of field trials, it was obtained the attitudes of students. This analysis aims to determine the value of the ability of students' attitudes in the categories very good, good, sufficient and less and very lacking. Based on the results of the analysis, it was found that the average ability of the students was $76.46 \%$ with a good category.

\section{Conclusion}

It is concluded that the character education-based poetry writing assessment instrument developed is effective in learning. Learning Indonesian, especially writing poetry based on character education which is served to students, aims to train students to be skilled in language, especially writing by expressing ideas and feelings creatively and critically. Learning to write poetry in high school according to the 2013 Curriculum aims to improve the skills of students in appropriate and creative language, increase the ability to think logically, critically and reason, and increase the sensitivity of feelings and the ability of students to understand and implement the values of character education in everyday life. day and in the school environment.

\section{References}

Andrianto, Tuhana Tufiq. 2011. Mengembangkan Karakter Sukses Anak di Era Cyber. Yogyakarta: Ar-Ruzz Media.

Anwar, Ilham. 2010. Pengembangan Bahan Ajar. Bahan Kuliah Online. Direktori UPI. Bandung.

Ashyar, Rayandra.2012. Kreatif Mengembangkan Media Pembelajaran . Jakarta : Referensi Jakarta.

Asriani, Piti. dkk. 2017. Bahan Ajar Berbasis Pendidikan Karakter untuk Siswa Kelas IV Sekolah Dasar. Jurnal Pendidikan: Teori dan Pengembangan Volume 2 Nomor 11 November 2017. Universitas Negeri Malang.

Barnawi \& Arifin. 2012. Strategi \& Kebijakan Pembelajaran Pendidikan Karakter. Yogyakarta: Ar-Ruzz Media.

Borg, Walter. R., and Gall. Meredith D. 1983. Educational Research an Introduction New York and London, Longman Inc.

Daryanto. 2013. Menyusun Modul : Bahan Ajar untuk Persiapan Guru dalam Mengajar. Yogyakarta : Gavamedia.

Depdiknas.2002. Teknik Belajar dengan Modul. Jakarta : Dirjen Pendidikan dasar dan Menengah.

Depdiknas. 2003. Undang-Undang No. 20 tahun 2003, Sistem Pendidikan Nasional,.

Depdiknas. 2003. Kamus Besar Bahasa Indonesia Edisi Ketiga . Jakarta : Balai Pustaka.

Depdiknas. 2008. Pengembangan Buku teks pelajaran [Online]. Tesedia: http://www.scribd.com/doc/5702869/11-Pengembangan-Bahan-Ajar [18 Agustus 2014].

Diponegoro, M. 2011. Nulis Cerpen Yuk! Jakarta : Narasi.

Direktorat Pembinaan SMA Ditjen Pendidikan Dasar dan Menengah. 2017. Modul Penyusunan Soal-Soal HOTS. Jakarta. 
Laksana. 2006. Ketatabahasaan dan Kesusastraan Cermat Berbahasa Indonesia. Bandung : Yrama Widya.

Machi, Koji. Teaching Materials. Jurnal Bahasa, Sastra, dan Pembelajaran, Volume 2, Nomor $1: 16$-27. Tokyo : Council of Local.

Majid, Abdul. 2011. Perencanaan Pembelajaran: Mengembangkan standar Kompetensi Guru. Bandung : PT Remaja Rosda Karya.

Marta, Redo Andi. 2014. "Peran Sastra dalam Pembentukan Pendidikan Karakter Anak Bangsa”. Wahana Didaktika (online) volume 12, No.3 /April 2017.

Munaward. 2011. Prinsip dan Prosedur Penulisan Modul. [Online]. Http:/marwarnard.blogspot.com/2011/11/11blog-spot.html. Diakses tanggal 19 Agustus 2014.

Muslich, Mansur. 2011. Pendidikan Karakter Menjawab Tantangan Krisis Multidimensional. Jakarta : Bumi Aksara.

Narwanti, Sri.2011. Pendidikan Karakter. Yogyakarta : Familia.

Nurgiantoro, Burhan. 2013. Teori Pengkajian Fiksi. Yogyakarta : Gadjah Mada University Press.

Richey, Rita C., and Klein, James D. 2007. Design Development and Research Methods, Strategies, and Issues. London. Lawrence Erlbaum Associates Publishers.

Ridwan, Muhamad. 2012. Menyemai Benih Karakter Anak. dari http://www. adzzikro.com

Russel D, James. 1997. Teknologi Pembelajaran dan Media untuk Belajar.

Salahudin, A. \& Irwanto Alkrienciehie. 2013. Pendidikan Karakter Berbasis Pendidikan Agama dan Budaya Bangsa. Bandung: CV Pustaka Setia

Sani, Ridwan Abdullah. 2014. Inovasi Pembelajaran . Jakarta : Bumi Aksara.

Siregar, S.H., Adisaputera, A., and Saragi, D. (2020). Development of Vocabulary Assessment Instrument Based on Information on Writing Materials for Explanatory Texts of 11th Grade Students Senior High School. Budapest International Research and Critics in Linguistics and Education (BirLE) Journal Vol 3 (2): 1190-1199.

Suherly, dkk. Bahasa Indonesia SMA Kelas XI. Jakarta : Kemendikbud.

Suyadi. 2012. Buku Panduan Guru Profesional - Penelitian Tindakan Kelas (PTK) dan Penelitian Tindakan Sekolah (PTS) Yogyakarta : Andi.

Tegeh, Made dkk. 2014. Model Penelitian Pengembangan. Yogyakarta: Graha Ilmu.

Wibowo, A. 2013. Manajemen Pendidikan Karakter di Sekolah. Yogyakarta: Pustaka Pelajar.

Winkel. 2009. Psikologi Pengajaran. Yogyakarta : Media Abadi.

Yohana, Solin, M., and Hadi, W. (2019). The Development of Instrument of Reading Literacy Assessment on Indonesian Language Learning in Quality Medan University. Budapest International Research and Critics in Linguistics and Education (BirLE) Journal Vol 2 (2): 372-387. 